\title{
Global scaling as a logic of multinationalization
}

\section{A. Rebecca Reuber ${ }^{1}$, Esther Tippmann ${ }^{2}$ and Sinéad Monaghan ${ }^{3}$}

${ }^{1}$ Rotman School of Management, University of Toronto, Toronto, Canada; ${ }^{2}$ J.E. Cairnes School of Business \& Economics, NUI Galway, Galway, Ireland; ${ }^{3}$ Trinity Business School, Trinity College Dublin, Dublin, Ireland

Correspondence:

AR Reuber, Rotman School of Management, University of Toronto, Toronto, Canada e-mail: becky.reuber@rotman.utoronto.ca

\begin{abstract}
Global scaling - defined as a logic of multinationalization that seeks rapid growth through the replication of a global business model across foreign markets - is an increasingly visible real-world phenomenon; however, it is one which has not yet been theorized in international business research. The purpose of this editorial is to initiate a dialogue that will lead to greater discussion and research in this area. We present the theoretical facets of the global scaling logic and compare global scaling with other conceptualizations of rapid international growth. We then draw on previous research in international business and entrepreneurship to suggest facilitators of global scaling. Finally, we highlight the challenges of global scaling and areas for future empirical research to help us better understand which kinds of firms are likely to follow a global scaling logic, and which factors contribute to its successful implementation. Throughout the discussion, we use published case studies as examples, in order to provide suggestions for teaching material on global scaling.

Journal of International Business Studies (2021) 52, $1031-1046$.

https://doi.org/ | 0.1057/s41267-021-00417-2
\end{abstract}

Keywords: global strategy; globalization; multinational enterprises (MNEs); rapid growth; replication; scaling

\section{INTRODUCTION}

A recent Harvard Business Review article declares that "scale now trumps differentiation" in firm strategy (Van Alstyne, Parker, \& Choudary, 2016: 54). Reid Hoffman, the founder of LinkedIn warns, "you have to move faster, because competition from anywhere on the globe may beat you at scale" (quoted in Sullivan, 2016: 46). Yet, despite such attention to global scaling by practitioners and policymakers, there is little discussion of global scaling in international business scholarship. The purpose of this editorial is to initiate a dialogue that will lead to greater discussion and research in this area. We begin by proposing a definition: Global scaling is a logic of multinationalization that seeks rapid growth through the replication of a global business model (i.e., a model based solely on nonlocation-bound firm-specific advantages) across foreign markets.

Understanding global scaling is important because it is a distinct logic of $\mathrm{MNE}^{1}$ internationalization, or multinationalization, that has not yet been explicitly theorized in international business. The Journal of International Business Studies has recently
Received: 19 May 2020

Revised: 4 February 2021

Accepted: 13 February 2021

Online publication date: 1 April 2021 
published several articles in which different logics of multinationalization are proposed. The updated Uppsala model (Vahlne \& Johanson, 2017) is based on an incremental logic (Håkanson \& Kappen, 2017: 1006). It holds that managers make internationalization commitments in pursuit of opportunities that fit their resources and capabilities, and through this they develop the knowledge and relational capital that enable them to pursue subsequent opportunities. Håkanson and Kappen (2017) build on the ideas of limiting downside risk and developing experiential knowledge to suggest an alternative - betting - logic of multinationalization. Their "Casino model" holds that MNEs limit their exposure to downside outcomes by establishing sales subsidiaries in multiple markets simultaneously. It is expected that some of these subsidiaries will fail, but this logic nonetheless allows the MNE to explore a broader set of new opportunities. Santangelo and Meyer (2017) build on the assumption of path dependencies within the Uppsala model. Based on an evolutionary logic, they contend that resource commitments to international markets can be either path-continuing or path-breaking over time; the latter being associated with higher risk and potentially higher returns. Each of these logics emphasize the exploration of new opportunities through multinationalization.

Clearly, entrepreneurial MNEs may go through a period of rapid international growth that is inconsistent with these logics, and is instead based on a replication strategy. A replication strategy de-emphasizes the exploration of new opportunities over time to drive growth (e.g., Chliova \& Ringov, 2017; Winter \& Szulanski, 2001). Instead, opportunity exploration occurs before international commitments in order to be able to develop and then execute a global business model.

While scholars have advocated global strategies based on standardization (e.g., Bartlett \& Ghoshal, 1989; Levitt, 1983; see Verbeke, 2013, for an overview), global scaling, as a distinct logic of multinationalization increasingly observed in the real world, has not yet been extensively theorized. In this editorial, we conceptualize global scaling and position it within the extant international business literature. The remainder of this editorial is organized as follows. First, we present the theoretical facets of the global scaling logic. We then compare global scaling with other conceptualizations of rapid international growth. Next, we draw on previous research in international business and entrepreneurship to suggest facilitators of global scaling. Finally, we highlight the challenges of global scaling and areas for future empirical research to help us better understand which kinds of firms are likely to follow a global scaling logic and which factors contribute to its successful implementation. Throughout the discussion, we use published case studies as examples, in order to provide suggestions for teaching material on global scaling.

\section{WHAT IS GLOBAL SCALING?}

Although "scaling" is a term that is used colloquially as a synonym for growth, analysis of past research shows that three different bodies of literature - economics, entrepreneurship, and strategic management - have highlighted different facets of it. These are summarized in Table 1 . In this section, we show that these three perspectives can be integrated through the notion of a business model: how the firm creates and captures value (Zott, Amit, \& Massa, 2011). A global business model is based on uniformity across country markets (Tallman, Luo, \& Buckley, 2018: 528) and embodies the nonlocation-bound firm-specific advantages - the intangible assets, learning capabilities, and relationships with outside actors (Rugman \& Verbeke, 2003: 127) - that reduce the costs and friction of entering foreign markets, thus enabling global scaling. In this section, we also highlight international business research which sheds light on the meaning of "global." Our conceptualization of the logic of global scaling builds on and integrates this prior research, as outlined below.

\section{Economics: Economies of Scale}

The international business literature often draws on the notion of scale in economics. Economies of scale are cost advantages associated with greater output volume, typically the decrease in the cost per unit of output that is associated with an increased volume of output. Thus, a firm that is scaling is increasing profits by increasing output volume and reducing per unit cost. The "outcome volume" is usually sales, but it can also be number of customers. While profitability is the ultimate goal of global scaling, an intermediate objective might be augmenting a user base that can be monetized later (Huang, Henfridsson, Liu, \& Newell, 2017). Here, the same argument applies, but it relates specifically to customer acquisition costs: there are economies of scale when the per customer acquisition cost decreases as more customers are acquired. 
Table 1 Multidisciplinary foundations of the global scaling logic

\begin{tabular}{|c|c|c|c|}
\hline & \multicolumn{3}{|c|}{ Scholarly foundations of global scaling } \\
\hline & Economics & Entrepreneurship & Strategic management \\
\hline $\begin{array}{l}\text { Meaning of } \\
\text { scaling }\end{array}$ & $\begin{array}{l}\text { Returns to scale are the changes in } \\
\text { production output associated with a } \\
\text { change in production input }\end{array}$ & Scaling is persistently rapid growth & $\begin{array}{l}\text { Scaling is the replication of a firm's } \\
\text { business model across new sites }\end{array}$ \\
\hline $\begin{array}{l}\text { Benefits of } \\
\text { scaling }\end{array}$ & $\begin{array}{l}\text { Profitability is achieved when output } \\
\text { volume increases and per unit costs } \\
\text { decrease }\end{array}$ & $\begin{array}{l}\text { Market competitiveness is achieved } \\
\text { when greater customer acquisition } \\
\text { leads to market domination }\end{array}$ & $\begin{array}{l}\text { Rapid geographic expansion is } \\
\text { achieved when a business model is } \\
\text { replicated in multiple locations }\end{array}$ \\
\hline $\begin{array}{l}\text { Role of } \\
\text { international } \\
\text { markets in } \\
\text { scaling }\end{array}$ & $\begin{array}{l}\text { International markets offer the } \\
\text { opportunity to sell more products, } \\
\text { which can increase profitability to the } \\
\text { extent that the cost of } \\
\text { multinationalization is low }\end{array}$ & $\begin{array}{l}\text { International markets offer the } \\
\text { opportunity to acquire more customers } \\
\text { and increase market share }\end{array}$ & $\begin{array}{l}\text { International markets need to be } \\
\text { homogeneous for the business } \\
\text { model to be replicated successfully } \\
\text { across markets }\end{array}$ \\
\hline $\begin{array}{l}\text { Relationship } \\
\text { among } \\
\text { perspectives }\end{array}$ & $\begin{array}{l}\text { Replication of a global business model } \\
\text { across markets reduces the cost of } \\
\text { multinationalization }\end{array}$ & $\begin{array}{l}\text { Replication of a global business model } \\
\text { across markets reduces the frictions of } \\
\text { multinationalization and increases the } \\
\text { speed of customer acquisition in new } \\
\text { markets }\end{array}$ & $\begin{array}{l}\text { A global business model reduces } \\
\text { the cost and friction, and increases } \\
\text { the speed, of entering new } \\
\text { markets }\end{array}$ \\
\hline
\end{tabular}

When international growth provides the opportunity to increase sales (or user acquisition) without a concomitant increase in costs, firms can reap these economies of scale and increase profitability (e.g., Caves, 1971; Contractor, 2007). The caveat "without a concomitant increase in costs" is key, because international expansion can be costly. Fast multinationalization in particular can limit the firm's ability to absorb expansion, leading to inefficiencies (Vermeulen \& Barkema, 2002), and so it is important to understand the costs associated with entry into new markets (Hennart, 2007; Verbeke \& Forootan, 2012). Thus, this economics lens highlights that economies of scale are an objective of a global scaling logic. A global business model that minimizes the costs of multinationalization, by enabling replication across country markets, is consistent with this objective.

\section{Entrepreneurship: Rapid Growth}

The entrepreneurship literature conceptualizes scaling differently, emphasizing the magnitude and persistence of firm growth in terms of sales or headcount. "Persistence" in this context means continued commitment in the face of difficulties (Cardon \& Kirk, 2015; Gimeno, Folta, Cooper, \& Woo, 1997). Rapid growth is time-limited, since permanent rapid growth is unsustainable (Garnsey, 1998; Hambrick \& Crozier, 1985). Scaling is normally operationalized as a growth rate exceeding $20 \%$ per year over a three-year period (see
Aernoudt, 2017; Coutu, 2014; Duruflé, Hellmann, \& Wilson, 2018), although it is not unusual for globally scaling firms to exceed a $40 \%$ compound annual growth rate (Izosimov, 2008; World Economic Forum, 2016).

In this literature scaling is undertaken for market dominance rather than cost reduction. Market dominance not only increases revenues, it also confers reputational advantages (Fischer \& Reuber, 2007; Roberts \& Dowling, 2002; Shamsie, 2003). When a market is characterized by network externalities (Katz \& Shapiro, 1994), early market dominance can also provide advantages such as technological dominance (Schilling, 2002) and dominance in establishing a loyal base of customers (Katz \& Shapiro, 1994). These are competitive advantages for scaling firms because they reduce constraints in sustaining competitiveness, and they also increase the prominence of the firm in local foreign markets (e.g., Couper \& Reuber, 2013).

Access to foreign countries is essential for persistent rapid growth if they provide a larger market than the firm's domestic one (Coutu, 2014; Erasmus Centre for Entrepreneurship, 2018; Scale Up Europe, 2016; Scale Up Institute, 2019). Both the economics and the entrepreneurship perspectives see a global business model as a non-locationbound firm-specific advantage that facilitates replication. The difference is that the focus of the entrepreneurship perspective is on uniformity of the firm's value proposition and value-creating and 
value-capturing mechanisms across country markets. Uniformity enables rapid growth by minimizing the time and resources required for local adjustments. We write "minimizing" rather than "eliminating" because some local adjustment is always required; for instance, a firm may need to factor in currency or language differences.

There is no assumption within the entrepreneurship perspective that scaling is related to firm profitability in the short-to-medium term. Many firms concentrate on acquiring ever more customers in order to achieve market domination in the present so as to garner monopolistic rents in the longer term. What is assumed is that scaling is expensive, and so firms need to tap into external "patient" capital to achieve rapid growth (Aernoudt, 2017; Duruflé et al., 2018). Reliance on external capital suggests that a third objective of global scaling may be the generation of exit options so that investors can reap the rewards of their investments.

\section{Strategic Management: Replication Strategy}

The replication strategy literature offers an explanation of firm growth that is explicitly related to geographic expansion and so of relevance to global scaling. This literature contends that firm growth is based on large-scale execution of an established business model through replication in new sites (e.g., Winter \& Szulanski, 2001), foreign markets in the case of global scaling (Chliova \& Ringov, 2017; Szulanski \& Jensen, 2008). The key to a successful replication strategy is having to make only minimal adaptations to the business model for its use in different sites (Szulanski \& Jensen, 2008; Winter, Szulanski, Ringov, \& Jensen, 2012).

Past international business research has shown that multinationalization is often accompanied by pressure to localize in order to respond to countryspecific demands (Bartlett \& Ghoshal, 1989; Prahalad \& Doz, 1987). However, Tallman et al. (2018: 528 ) argue that a global business model can exist in the absence of strong and diverging pressures for local adaptation when there is uniformity in the firm's value proposition and activity system across countries and regions. Thus, the extent to which a business model is global reflects the extent to which it is replicable across geographic space, as well as the extent to which it represents a nonlocation-bound firm-specific advantage facilitating global scaling.

Firms that follow a replication strategy "frontload" the exploration of opportunities to develop a business model which can be replicated on a large scale (Winter \& Szulanski, 2001: 731). Such frontloading is consistent with practitioner insights on the importance of finding product-market fit and a viable business model before scaling (Cohen, 2020; Isenberg \& Lawton, 2014; Sullivan, 2016).

The three dimensions of global scaling discussed so far are integrated through the notion of a business model. We turn now to a fourth aspect of global scaling: globalness.

\section{International Business: Globalness}

A fourth body of literature on which we base our conceptualization of global scaling is the international business literature on globalness. The term "global" has become contentious in that literature, with some arguing that it has been applied too readily to firms that are regional but not global, and suggesting that some thresholds should be applied to determine if a firm is truly global (see Osegowitsch \& Sammartino, 2008; Rugman \& Verbeke, 2004, 2008; Verbeke, Coeurderoy, \& Matt, 2018). Such discussions beg the question of what differentiates global scaling from domestic scaling or regional scaling, and even whether the label "global" should be used at all. We contend that that label is appropriate because the foundation on which scaling rests - economies of scale, rapid growth, and replication - is inherently geographically unbounded. Thus, globalness is an objective of global scaling.

Although the logic of global scaling is not compromised by geographic boundaries, the extent to which firms are global at a specific point in time will vary. The five criteria of globalness proposed by Verbeke et al. (2018) are shown in Table 2, together with some considerations of how to operationalize each of them to determine whether a firm has achieved "global" scaling. We see the first two criteria - non-location-bound firm-specific advantages, and global ambition on the part of management - as fundamental characteristics of firms following a global scaling logic. However, the remainder - achieving global breadth and depth of assets and sales, and the scope of value chain activities - are variable over time as an MNE engages in scaling (e.g., see Osegowitsch \& Sammartino, 2008). Further, an MNE may be more globalized in one dimension than in another; for instance, sales may be more globalized than human assets if an MNE waits for a certain threshold of sales in a target country or region to open a sales subsidiary there. 
Table 2 The multidimensionality of "globalness"

Non-location-bound firm-specific advantages

Global ambitions on the part of management

Significant geographic breadth

Significant geographic depth
Description and operationalizations

Proprietary knowledge, technology, brands, practices, routines, and capabilities that support the global business model and are replicable across multiple regions

Statements regarding global ambitions or achievements by a firm's leaders. Outside investment explicitly made to support global scaling. Standardized international branding and corporate design (Lovelock \& Yip, 1996)

A presence in many countries. The number of countries in which a firm has assets/sales. The number of country-specific domains of a firm's website and social media accounts (e.g., Facebook page or Twitter account)

A significant percentage of overall assets/sales in multiple regions. Having sales of $20 \%$ or more in each region of the triad (North America, Europe, Asia Pacific), but less than $50 \%$ in any one region (Rugman \& Verbeke, 2004). Less stringent measures are suggested by Osegowitsch and Sammartino (2008)

A wide scope of value chain activities in the firm's international operations (internally or through value chain partners)

Value chain activities located in multiple regions. The key value chain activities to consider may be industry-specific (e.g., Lovelock \& Yip, 1996; Rugman \& Verbeke, 2008)

Adapted from: Verbeke, Coeurderoy and Matt (2018).

\section{Definition of Global Scaling}

We integrate the four bodies of literature we have outlined to define global scaling as a logic of multinationalization that seeks rapid growth through the replication of a global business model across foreign markets. The four goals of global scaling - economies of scale, market dominance, exit options, and globalness - are shown in Figure 1. The persistence and rapidity of growth, the precision of replication, the globalness of the business model, and the number of foreign markets will vary in practice across firms pursuing global scaling. Therefore, global scaling is not a binary classification, and some firms will scale globally more extensively than others. Moreover, there are considerable challenges in global scaling, as we will discuss later; rapid growth is achieved by less than $10 \%$ of firms in OECD countries (Audretsch, 2012). Thus, a firm's achievement of global scaling may fall short of the intentions of its leaders.

\section{GLOBAL SCALING COMPARED WITH OTHER CONCEPTUALIZATIONS OF RAPID INTERNATIONAL GROWTH}

\section{Global Scaling Versus Early Internationalization}

A rich international entrepreneurship literature emphasizes early and accelerated internationalization (e.g., Knight \& Cavusgil, 2004; Oviatt \& McDougall, 1994; Reuber, 2018). It can be differentiated from the logic of global scaling in two key ways. First, they do not share core characteristics. The early internationalization literature pays little to no attention to persistent and rapid growth, to higher internationalization commitment modes, or to a replication strategy. It usually measures the rapidity of international growth by the speed with which a firm attains a threshold level of sales in foreign markets within a certain time after startup, and the threshold level of sales is often modest and unrelated to growth. For example, Zahra, Ireland and Hitt (2000) set the marker at five per cent within six years, and Zhou, Wu and Luo (2007) set it at ten per cent within three years. The resource commitment to any foreign market is largely left unexamined because the focus is on exports (Cavusgil \& Knight, 2015; Chetty, Johanson, \& Martín Martín, 2014).

The second distinction is an emphasis in the early internationalization literature on the age of the firm when it starts to sell internationally. Our conceptualization of global scaling is agnostic as to how long after start-up the firm starts selling abroad. There is in fact likely to be a gap between start-up and the beginning of a period of global scaling, because uncertainty limits entrepreneurs' 
ability to predict the market at inception, and early market and product changes are often made (Dencker, Gruber, \& Shah, 2009). It may therefore be some time before a viable global business model can be put in place and "premature scaling" avoided. For example, Netflix was 13 years old before it entered its first foreign market, after which it scaled globally (Brennan, 2018).

Despite these differences, in practice, some firms will internationalize early and will also scale globally. They may be able to do so because they have developed a global business model soon after startup (see Hennart, 2014). Alternatively, they may start exporting early and then begin scaling globally once they have a replicable global business model in place. However, there is no theoretical reason to see these two types of internationalization behaviors as linked. Indeed, Hashai (2011) finds that early internationalizing firms lack the capabilities to both expand geographically and have high commitment modes, and their choice between these paths sticks over time. This suggests that firms which are early exporters may develop and leverage export capabilities rather than capabilities to multinationalize.

Finally, although we contend that early internationalizing firms are theoretically distinct from globally scaling firms, the early internationalization literature provides some important insights into firm-level and market-level facilitators of global scaling. We discuss these later in this editorial, but first compare global scaling and rapid multinationalization.

\section{Global Scaling Versus Rapid Multinationalization} In the MNE literature, "rapid international growth" usually means a high speed of foreign direct investment expansion, i.e. setting up many new subsidiaries in a short period of time (Chang \& Rhee, 2011; Vermeulen \& Barkema, 2002; Yang, Lu, \& Jiang, 2017). A high commitment to particular foreign markets is assumed because expansion involves investment in a new location. International expansion at high speed is challenging because time compression diseconomies (Dierickx \& Cool, 1989), and limits to absorptive capacity (Cohen \& Levinthal, 1990) restrict experiential learning (e.g., see Monaghan \& Tippmann, 2018; Vermeulen \& Barkema, 2002; Yang et al., 2017). In contrast to the international entrepreneurship literature, the firms studied in the MNE literature are usually well-established and mature - the mean firm age is 30 in Chang and Rhee (2011) and 45 in
Yang et al. (2017) - which reflects the fact that many MNEs exhibit rapid international growth at a mature stage (e.g., Bartlett \& Ghoshal, 2000).

Since global scaling is a logic of multinationalization, it is consistent with the broader multinationalization literature in its emphasis on foreign operations (vs. exporting) and on speed of growth. At the same time, there are three differences. Global scaling is based on a replication strategy that emphasizes growth in sales, employment and/or assets, and not necessarily short-term profitability. In contrast, the literature on rapid internationalization of MNEs stresses the costs of local adjustments rather than the benefits of replication, emphasizes geographic expansion - in particular the number of subsidiaries established over time rather than other growth metrics, and pays attention to shorter-term profitability (or lack thereof) as the key outcome of rapid international growth (Chang \& Rhee, 2011; Vermeulen \& Barkema, 2002; Yang et al., 2017). Despite these differences, the multinationalization literature is valuable for understanding the challenges of global scaling in that it shows how global scaling is hindered by the organizational difficulties caused by rapid geographic expansion, as we will discuss later.

\section{THE FACILITATORS OF GLOBAL SCALING}

The international business and entrepreneurship literatures suggest facilitators of global scaling that are both internal and external to the firm. We discuss them in this section and summarize them in Figure 1. We first present the facilitators of rapid international growth and then those of replication. We do this because past research tends to focus on one or the other, and so separating them in our discussion provides a clearer explanation of the likely relationships between a facilitator and outcome(s) of global scaling.

\section{Facilitators of Rapid International Growth}

\section{Facilitators of rapid international growth internal to the firm}

A large body of entrepreneurship research shows that the human, social, and relational capital of entrepreneurs and entrepreneurial teams, especially their experience, are associated with higher growth of their firms (e.g., Demir, Wennberg, \& McKelvie, 2017; Eisenhardt \& Schoonhoven, 1990; Gilbert, McDougall, \& Audretsch, 2008). The international entrepreneurship literature echoes these findings 


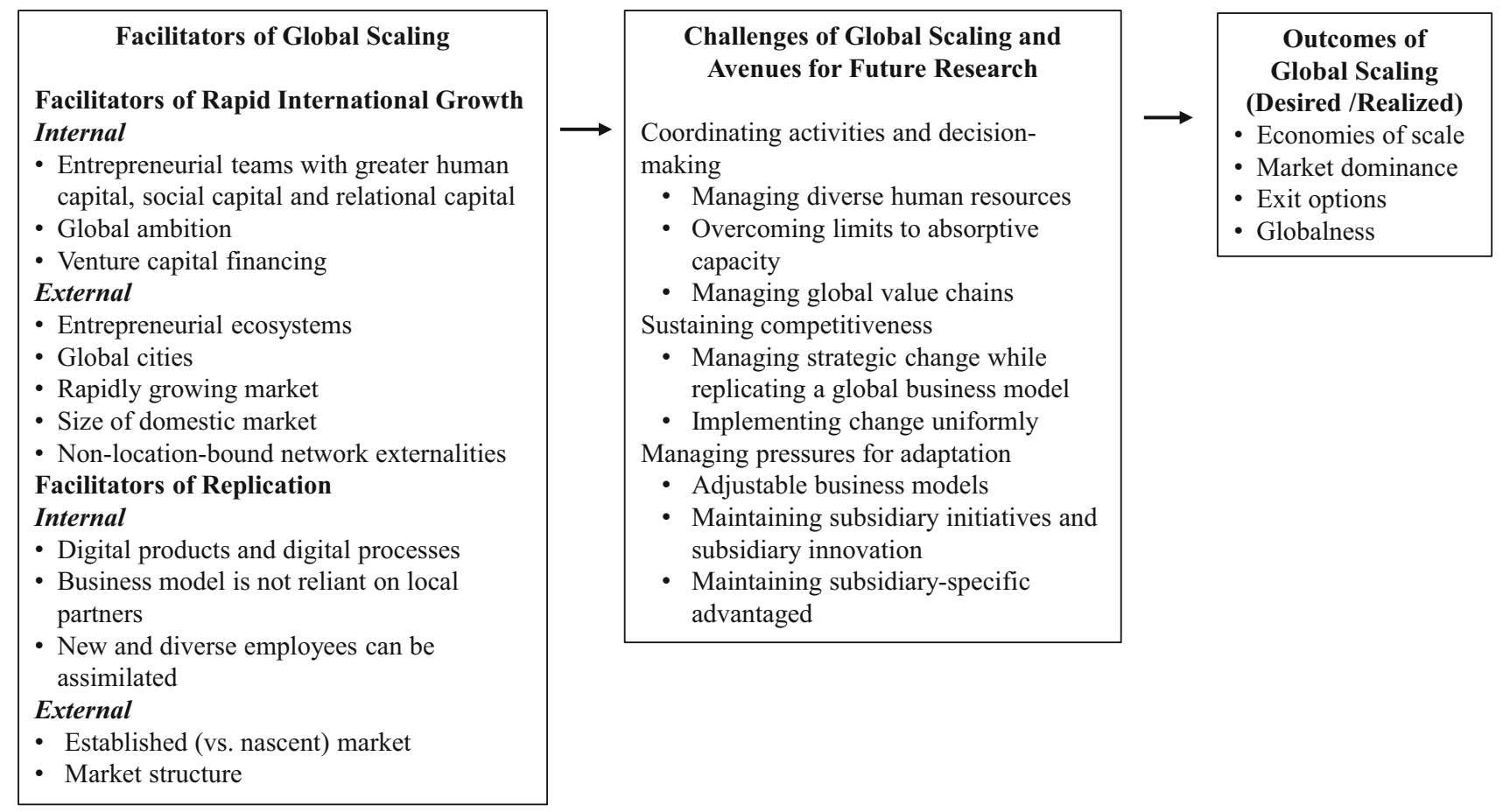

Figure 1 Global scaling: Facilitators, outcomes, challenges, and avenues for future research

and shows that, in young and inexperienced firms, individual-level characteristics, such as experience, can compensate for a lack of firm-level experience, and that this can facilitate rapid international growth (Autio, 2005; Oviatt \& McDougall, 1994; Reuber, 2018; Reuber \& Fischer, 1997). We therefore expect entrepreneurial teams with greater human, social, and relational capital to be more likely than less well-endowed teams to view global scaling as the desired outcome and to be better able to achieve it. ${ }^{2}$

Similarly, we expect teams with greater global ambitions at start-up to pursue global scaling. Again, from the international entrepreneurship literature, McDougall, Shane and Oviatt (1994) argue that many firms develop from start-up the competencies well-suited to their domestic market. This can result in "domestic inertia" through path dependencies, making subsequent internationalization difficult. On the other hand, when entrepreneurial teams have global ambitions from the outset, they are likely to prioritize the development of a global business model, making it more likely that the move from domestic to international customers will be anticipated and planned for.

Rapid growth requires large amounts of capital, and so tends to be unprofitable (Hambrick \& Crozier, 1985; Markman \& Gartner, 2002).
Accordingly, outside investment, normally from venture capitalists, is required to fuel global scaling (Aernoudt, 2017; Duruflé et al., 2018). These investors can share experiential knowledge about global scaling with the entrepreneurial team, and also provide valuable social, relational, and reputational capital (see Fernhaber \& McDougall-Covin, 2009). They can also fuel global ambitions, as we see in the global scaling of the Indian hotel chain, $\mathrm{OYO}$, where an investor recommended faster and more aggressive global scaling earlier than the firm's founder had considered (Ramaswamy \& Hellpap, 2020). Further, venture capitalists typically require an exit strategy, and may therefore prefer international growth to product line diversification, so as to make the firm a more attractive acquisition target (Pitelis, 2020). Thus, venture capital financing is likely to be associated with all the outcomes of global scaling shown in Figure 1.

\section{Facilitators of rapid international growth external to the firm}

There are also factors external to the firm that prior literature suggests will be related to global scaling as a desired, and a realized, outcome. Firms located in an entrepreneurial ecosystem can draw on ecosystem support for specialized human capital, funding, and the indirect resources which aid the 
development and implementation of scalable business models, such as advisors, mentoring programs, partners, technology provision, and workspaces (e.g., Autio, Nambisan, Thomas, \& Wright, 2018). Also, at the ecosystem level, global cities ease the cost and friction of geographic expansion by reducing the liabilities of foreignness and outsidership when establishing subsidiaries (see Goerzen, Asmussen, \& Nielsen, 2013). Not only can this support rapid international growth, but it can also facilitate replication by lessening pressure to adapt operations locally; for instance, allowing the MNE to work with the same service providers across borders and to draw on common norms for managing a cosmopolitan work force.

Similarly, there are market-related factors that facilitate global scaling. It is easier for firms to internationalize rapidly when there are competitive pressures to do so (Chang \& Rhee, 2011), and when the global market itself is growing rapidly (Hambrick \& Crozier, 1985). For example, the global scaling of the restaurant franchisor, Freshii, was facilitated by the high worldwide growth of the fast-casual category of restaurants (Lim \& Chandrasekhar, 2018). Freshii stands out, because it is not in a high-tech industry, unlike many other companies used as examples of globally scaling firms. In fact, a recent Brookings Institution study of Inc. Magazine's list of 5,000 fast-growing businesses in the U.S. shows that, while high-tech firms are more likely than other firms to be characterized by rapid growth, the majority of rapid growth firms are nonetheless not in high-tech industries (Hathaway, 2018). To our knowledge, similar data are not available for globally scaling firms, but these numbers suggest that such firms may be present in a variety of industries.

Domestic market size may also facilitate global scaling. Firms that are founded in small domestic markets may internationalize early, as international expansion is the only way they can grow (Fan \& Phan, 2007). Freshii could not have achieved its growth ambitions based on the Canadian market alone. Leaders of growth-oriented firms in smaller domestic markets are more apt to develop internationalization-related competencies earlier than firms started in large domestic markets (Reuber \& Fischer, 1999), and we therefore expect them to prioritize international markets when developing their business model. This means that the firms in small domestic markets may attempt to scale globally earlier than firms in large domestic ones.
In contrast, firms that are founded in large domestic markets, such as the US and China, may have sufficient demand in their home market to be able to scale domestically. This could delay consideration of the needs of foreign markets when developing a scalable business model. However, being able to evolve the business model on a large scale domestically, and garnering a reputation as an industry leader, may facilitate subsequent global scaling, although later in the firm's life. An example of this is Qualtrics, which was recognized as an industry leader among online survey software providers when it started to scale globally at the age of 12 years (Tippmann \& Monaghan, 2018).

Finally, if network externalities are important, global scaling is facilitated by the presence of nonlocation-bound, or cross-country, network externalities. Due to network (Katz \& Shapiro, 1994) and/or herd (e.g., Banerjee, 1992) effects, the value of an offering for a market participant rises as their number increases, regardless of their geographic location (see Stallkamp \& Schotter, 2021). If there are cross-country network externalities, growth in one country market can increase demand in others.

\section{Facilitators of Replication}

\section{Facilitators of replication internal to the firm}

Prior research suggests three internal factors that are likely to facilitate the replication facet of global scaling. The first is having digital products and processes, since digital objects can be replicated quickly and cheaply (Autio, Mudambi, \& Yoo, 2021; Monaghan, Tippmann, \& Coviello, 2020). Digital platforms can enable localization in a replicable manner, such as local offerings on the Airbnb platform. For globally scaling firms, it is likely that digitization of processes supporting downstream activities, close to the customer, are particularly consequential for the feasibility of global scaling, because they are associated with greater pressure for local adaptation and so are more difficult to replicate (see Lovelock \& Yip, 1996; Rugman \& Verbeke, 2008).

There is high public visibility of digital platforms that have globally scaled successfully, and indeed digital products and processes facilitate replication, but this does not mean that digitization is either necessary or sufficient for global scaling. A firm can scale globally without a digital market offering, as shown by two examples we have already given: Indian hotel chain OYO and Canadian franchisor Freshii. And digitization is not sufficient to achieve 
global scaling. This is illustrated by the case of mobile money service provider, M-Pesa, which scaled within its home market of Kenya, but was unable to repeat that success in other markets (Wining \& Eaves, 2020).

As affiliations with local market actors may be part of a firm's global business model (e.g., Dees, Anderson, \& Wei-Skillern, 2004), we point to a second factor likely to impact replicability: reliance on local partners. Replicability will be facilitated to the extent there is a common way to establish and maintain effective partnerships across countries. Returning to Freshii, there is a standardized way to select and manage franchisees (Lim \& Chandrasekhar, 2018). An extreme example of complex local partnerships hindering global scaling is Temptime. Temptime offers a miniaturized monitor that indicates whether a vaccine has lost potency due to heat exposure. Globally scaling the adoption of this life-saving technology took decades because of the complexities of setting up and managing international distribution partnerships with public, private, and non-governmental organizations (Schifrin \& Davis, 2016).

Third, global scaling is likely to be facilitated by the extent to which a firm can assimilate new employees from different cultures. Garnsey (1998) argues that fast assimilation of newcomers is important to a firm's ability to grow rapidly. Assimilation involves a cross-cultural work force when a firm is replicating a global business model in multiple regions. In particular, it is important for firms to find replicable ways to manage an increasingly large and diverse work force (see, e.g., Reiche, Lee, \& Allen, 2019) and to support effective collaboration across national boundaries (see, e.g., Hinds, Liu, \& Lyon, 2011). To this end, the leaders of both Freshii (Lim \& Chandrasekhar, 2018) and Qualtrics (Monaghan \& Tippmann, 2018) worked hard to establish a strong organizational culture across locations and a tight person-organization fit with each new hire or franchisee.

\section{Facilitators of replication external to the firm}

The nature of the market can facilitate the replication facet of global scaling in at least two ways. The first has to do with whether the firm is in an established market or is creating a new one. In an established market, there are established business model types that new firms can adopt. We look again at Freshii and Qualtrics: the first adopting a known franchising business model and the second a known Software-as-a-Service one. Being able to do so does not make it easier to succeed in a global market - it is still necessary to identify opportunities with homogeneous user needs and to overcome the challenges of global scaling - but being able to adopt a well-known business model, rather than having to invent a new one as was the case with Netflix, may enable firms to start global scaling earlier.

A market structure that favors globalization is a second facilitator of replication, and by extension of global scaling. Competition in global markets takes place on a worldwide basis, and so firms face competition worldwide, whereas it occurs on a country-by-country basis in multidomestic markets where competitors are local (Porter, 1986). Replication is facilitated in global markets because competitors are (at least partially) the same across markets, and customers are seeking standardized products and processes (Lovelock \& Yip, 1996). In the business-to-business sphere, the latter may include MNEs looking for a common supplier worldwide. Further, during a firm's period of rapid growth, marketing activities are important in sustaining competitive advantage, and having to localize pre-sales and post-sales processes for multidomestic competition may impede global scaling (see Almor, Hashai, \& Hirsch, 2006).

The nature of government policies and regulations is another aspect of market structure (Porter, 1986). Government regulations put in place to help local firms get established in the home market will lessen the global nature of the market and hinder global scaling if they are difficult to replicate in other countries. Two examples of this are Kenyan banking regulations in the case of M-Pesa (Wining \& Eaves, 2020), and the barring of Google in China in the case of WeChat (Verbeke \& Hutzschenreuter, 2021).

\section{THE CHALLENGES OF GLOBAL SCALING AND PROMISING AVENUES FOR FUTURE RESEARCH}

More empirical research is needed if we are to have a better understanding of global scaling as a distinct logic of multinationalization. A good place to start would be with the facilitators of global scaling. While the factors we discuss above have already been identified as facilitators of either rapid growth or replication, they have not been studied for global scaling per se. We believe that it would be valuable to study their explicit relationship with global scaling, especially because the success stories of high-profile, even "celebrity", global scaling 
firms have propagated global scaling stereotypes. There are publicly available accounts of the global scaling of well-known Silicon Valley unicorns, but less well-known firms have also scaled globally, sometimes in less visible sectors, and across a wide variety of countries. We need to know more at a basic demographic level about the factors affecting the propensity to multinationalize with a global scaling logic, and conversely about the conditions making the development of a global business model difficult, or even impossible.

The presence or absence of a global scaling facilitator is unlikely to have symmetric effects if there are ways to compensate for gaps within the firm or for unfavorable market conditions. This suggests that it is likely that there are different pathways to achieving global scale across firms, especially as scale-up modes with distinct activity configurations have already been observed among unicorn firms (Piaskowska, Tippmann, \& Monaghan, 2021). It is also likely that there will be mutually reinforcing relationships among facilitators, for instance, venture capitalists will be more interested in financing innovative firms led by talented entrepreneurs with a globally scalable business model. Further empirical research is needed to untangle the relationships among global scaling facilitators and outcomes, perhaps using methods such as fsQCA (Fiss, 2011) that highlight alternate pathways or configurations associated with an outcome, or through the analysis of largescale quantitative datasets, cross-sectional or longitudinal, that focus on hypothesized relationships and control for alternate explanations.

Prominent success stories can mask how difficult it is to achieve global scaling. Practitioners and policymakers who monitor entrepreneurial firms report that most firms with high-growth potential are unable to scale successfully (Coutu, 2014; Erasmus Centre for Entrepreneurship, 2018; Scale Up Europe, 2016; Scale Up Institute, 2019). There are known difficulties in managing rapid growth (e.g., DeSantola \& Gulati, 2017; Penrose, 1959/ 1995), a replication strategy (Winter \& Szulanski, 2001; Zook \& Allen, 2012), and rapid international expansion (Monaghan \& Tippmann, 2018; Vermeulen \& Barkema, 2002; Yang et al., 2017). Collectively, these lead to three challenges for firms attempting to scale globally: coordinating activities and decision-making within a rapidly growing firm, sustaining competitiveness when relying on a replication strategy, and managing pressures for local adaptation of the global business model. Each of these challenges calls for new avenues of research. We discuss them below.

\section{Coordinating Activities and Decision-Making}

There are known organizational challenges in managing high growth. First, managers need to maintain the proper functioning of existing organizational structures, processes, roles, and culture, and at the same time manage the increased organizational complexity that results from adding large numbers of newcomers to the organization (DeSantola \& Gulati, 2017; Penrose, 1959/1995). Some have characterized the internal atmosphere of a rapidly growing firm as chaotic, with low role clarity and the concomitant threat to employee morale (e.g., Hambrick \& Crozier, 1985; Sullivan, 2016). We expect such challenges to be pronounced when rapid growth is globalized and involves an increasingly diverse work force. Globally scaling firms tend to emphasize a strong organizational culture as the "glue" holding the organization together, the case studies on Freshii (Lim \& Chandrasekhar, 2018) and Qualtrics (Monaghan \& Tippmann, 2018) serving as good illustrations. Future research might examine the extent to which cultural and structural approaches are effective (see Nohria \& Ghoshal, 1994; Rugman \& Verbeke, 2001).

Studies have shown that an organization's human resource management practices are critical mechanisms to enable rapid growth, because of the importance of recruiting, training, and incentivizing talent at a fast pace (Demir et al., 2017). Prior research suggests that MNEs characterized by centralized processes and uniform markets - such as those following a multinationalization logic of global scaling - should centralize global talent management (e.g., Morris, Snell, \& Björkman, 2016). However, research in this area tends to focus on established MNEs and stable practices, so it would be beneficial to identify effective practices which can be replicated across multiple regions while a firm is rapidly growing.

The limits to absorptive capacity are a second reason why it is challenging to coordinate activities and decision-making in a globally scaling firm. Cohen and Levinthal (1990) show that a firm's absorptive capacity is not only impacted by its ability to acquire or assimilate knowledge but also by its ability to share it within the organization. When a firm is globally scaling, communication patterns among people and across organizational units needs to evolve fast because of the influx of 
new employees. Thus, an important question for future research on global scaling is how firms overcome limits to absorptive capacity.

A third area for future research is global value chains. We were not able to find any explicit examination of how globally scaling firms manage their value chains, but we expect that centralized management of supply chain partners, like that of human resources, is consistent with a replication strategy. Freshii managed its supply chain centrally, although its franchisers sourced ingredients locally: the local suppliers were accredited by the company's central supply chain team (Lim \& Chandrasekhar, 2018). Such tight, centralized control is likely to become more difficult as value chain partners increase in number and diversity. This is shown by the difficulties Temptime experienced managing multiple vaccine manufacturers and community health care workers in multiple countries who were tasked to deliver vaccines (Schifrin \& Davis, 2016). The costs of coordinating, controlling, and integrating external actors are substantial under any circumstances (Larsen, Manning, \& Pedersen, 2013), and they are likely to increase under conditions of rapid growth. Future research might investigate the trade-offs for globally scaling firms in setting up and maintaining global value chains.

Future research might also examine the role of relational governance, an important coordinating mechanism in value chain relationships (Kano, 2018). We believe that the fast pace of global scaling tests the limits of trust as a coordination mechanism. Indeed, Couper, Reuber and Prashantham (2020) show that trust can become a source of hazard when international partnerships are formed too readily. This suggests that, compared to firms with more stable operations, globally scaling firms may need stronger safeguards to protect against bounded reliability (see Kano \& Verbeke, 2015; Verbeke \& Greidanus, 2009). Future research could consider what mechanisms are effective in this regard.

\section{Sustaining Competitiveness}

To remain competitive, globally scaling firms need to manage strategic change while replicating a global business model. The rapid growth of globally scaling firms is usually at least partially due to a rapidly growing market (Hambrick \& Crozier, 1985), and, in a fast-moving business environment, firms must innovate to remain competitive. This can result in what Winter and Szulanski (2001: 737) call the replication dilemma, which is a trade-off between replicating the current global business model and changing it. One pattern globally scaling firms can adopt to take advantage of new opportunities is that of successively adding product markets. For example, SurveyMonkey added product functionality to move into the enterprise market for online survey software after it had been globally scaling in the consumer market for several years (Rosenthal, Burgelman, \& Siegel, 2014). Similarly, Beekeeper, a Swiss firm providing a workplace communication platform, scaled globally by selling to customers in the hospitality industry before moving on to customers in other industries (Chauvet \& Leleux, 2019). Future research might examine the factors that smooth or delay such transitions.

Further, when the global business model shifts or expands for strategic reasons, the objective is to replicate it precisely. However, the implementation of strategy is dependent on diverse and dispersed participants with specific understandings based on the market responses they observe (see Feldman \& Pentland, 2003), so a once uniform global business model may come to vary across the organization. Future research could investigate the factors that might facilitate implementing a successful strategic reorientation while still retaining replicated processes.

\section{Managing Pressures for Local Adaptation}

Strategic reorientations are not the only reason to modify a global business model; there is likely to be pressure to make local adaptations. The classic literature on the MNE emphasizes the importance of managing the "local" and the "global" simultaneously (Bartlett \& Ghoshal, 1989; Prahalad \& Doz, 1987). We contend that this is likely to also hold true for globally scaling firms. For example, SurveyMonkey found that providing sufficiently nuanced language translation, and handling multiple currencies on websites visited by customers in 190 countries, required more than the straightforward adaptations they had envisioned (Rosenthal et al., 2014). Further, product differences were needed to support cross-country differences in how people respond to surveys (Orleans \& Siegel, 2019). Similarly, Qualtrics realized that the insidesales model that worked in the US had to be adapted when it expanded to Europe because personal relationships mattered more there when selling to business customers (Tippmann \& Monaghan, 2018). 
Adaptations of the kind we touch on above are inconsistent with a replication strategy. Precise replication of an established business model, versus making local adaptions or developing local innovations, has been found to be associated with lower failure and higher performance in a new location (Winter et al., 2012). Adapting a business model can be risky, as one adaptation can lead to many others, resulting in the unraveling of the business model's logic and to ineffective local operations (Winter et al., 2012). How can the desirability of preserving a successful business model be reconciled with a need for local adaptation? Jonsson and Foss (2011) show that IKEA went through a rigid replication stage before starting to accommodate a more flexible replication, but it took 15 years. It would be beneficial to examine how business models can be rapidly adjusted within a globally scaling firm. What business model characteristics accommodate fast adjustments? What accommodations might be made without incurring the replication costs found by previous researchers? Past research suggests that it may be fruitful to address these questions by examining certain types of activities in the business model: for example, focusing on core activities (Szulanski \& Jensen, 2006) or digitized activities (Autio et al., 2021), by differentiating between upstream versus downstream activities (Rugman \& Verbeke, 2008), or by considering hierarchies of activities (Jonsson \& Foss, 2011).

Future research might also investigate the roles of subsidiary innovation and initiatives in the context of global scaling. MNEs need to take advantage of the innovative and entrepreneurial potential of their geographically dispersed subsidiaries (Bartlett \& Ghoshal, 1989; Birkinshaw, 1997) in order to develop firm-specific advantages for the MNE as a whole (e.g., Birkinshaw, Hood, \& Jonsson, 1998). While subsidiary innovation and initiatives benefit from local autonomy, they need to be coordinated across the firm (e.g., Ghoshal \& Bartlett, 1988; Gupta \& Govindarajan, 2000). Given the difficulty of implementing effective control mechanisms in rapidly growing firms (Hambrick \& Crozier, 1985), we need to understand whether globally scaling firms can preserve the replicability of their global business model and at the same time reap the benefits of subsidiary innovation and initiatives, and, if they can, how? This is especially important when subsidiaries create competences that are embedded in their location and may therefore be location-bound (see Rugman \& Verbeke, 2001).
This suggests that future research might fruitfully consider how subsidiary-specific advantages can be retained in globally scaling firms.

\section{CONCLUSION}

Global scaling is already prevalent in some industries. It is a distinct multinationalization logic that poses a fascinating puzzle for international business scholars because it embodies tensions between growth and control, stability and change, and replication and adaptation. We hope that this editorial will be a catalyst for others to join us in exploring these tensions, in order to advance our theoretical and empirical understanding of global scaling.

\section{ACKNOWLEDGEMENTS}

We are grateful for the insights and feedback provided Alain Verbeke and three anonymous reviewers. We thank Peter Buckley and seminar participants at the University of Calgary, the University of Leeds, the University of Sheffield and King's College London for their valuable suggestions. The first author would like to acknowledge the financial support of the Social Science and Humanities Research Council of Canada.

\section{NOTES}

${ }^{1}$ Consistent with Buckley and Casson (2009), we use the term "multinational enterprise" (MNE) to denote a firm-level multinationality that is broader than internalization. It emphasizes the ownership and/or control of intermediate assets deployed abroad and encompasses subsidiaries, joint ventures, licensing, sub-contracting, and franchises, but not a sole focus on exporting. In the case of exports as the exclusive mode of foreign entry, the MNE's coveted firm-specific advantages are typically embodied in the exported products themselves. Most large MNEs do, however, engage in exports as one among several foreign operating modes (inter alia as a result of intra-firm trade). MNE activity may also include digital platforms as meta-organizations with hybrid market/hierarchy governance structures (see Gulati, Puranam, \& Tushman, 2012; Kretschmer, Leiponen, Schilling, \& Vasudeva, 2020)

${ }^{2}$ Other firm-level facilitators of rapid growth (Demir, Wennberg \& McKelvie, 2017), such as innovativeness and dynamic capabilities, have also 
been associated with successful internationalization (e.g., Teece, 2014; Venaik, Midgley, \& Devinney, 2005); however, we exclude these from our discussion, because they are associated with most, if not all, logics of multinationalization, and so are not particular to global scaling.

\section{REFERENCES}

Aernoudt, R. 2017. Executive forum: The scale-up gap: And how to address it. Venture Capital, 19(4): 361-372.

Almor, T., Hashai, N., \& Hirsch, S. 2006. The product cycle revisited: Knowledge intensity and firm internationalization. Management International Review, 46(5): 507-528.

Audretsch, D. B. 2012. Determinants of high-growth entrepreneurship. Report prepared for the OECD/DBA International Workshop on High-growth firms: local policies and local determinants. https://www.oecd.org/cfe/leed/ Audretsch_determinants\%20of\%20high-growth\%20firms.Pdf Accessed 12 December 2012.

Autio, E. 2005. Creative tension: The significance of Ben Oviatt's and Patricia McDougall's article 'toward a theory of international new ventures.' Journal of International Business Studies, 36(1): 9-19.

Autio, E., Mudambi, R., \& Yoo, Y. 2021. Digitization and globalization in a turbulent world: Centrifugal and centripetal forces. Global Strategy lournal, 11(1): 3-16.

Autio, E., Nambisan, S., Thomas, L. D. W., \& Wright, M. 2018. Digital affordances, spatial affordances, and the genesis of entrepreneurial ecosystems. Strategic Entrepreneurship Journal, 12(1): 72-95.

Banerjee, A. V. 1992. A simple model of herd behavior. Quarterly Journal of Economics, 107(3): 797-817.

Bartlett, C. A., \& Ghoshal, S. 1989. Managing across borders: The transnational solution. Boston: Harvard Business School.

Bartlett, C. A., \& Ghoshal, S. 2000. Going global: lessons from late movers. Harvard Business Review, 1(3): 75-84.

Birkinshaw, J. 1997. Entrepreneurship in multinational corporations: The characteristics of subsidiary initiatives. Strategic Management Journal, 18(3): 207-229.

Birkinshaw, J., Hood, N., \& Jonsson, S. 1998. Building firmspecific advantages in multinational corporations: The role of subsidiary initiative. Strategic Management Journal, 19(3): 221-241.

Brennan, L. 2018. How Netflix Expanded to 190 Countries in 7 Years. Harvard Business Review (Digital Article), https://hbr.org/ 2018/10/how-netflix-expanded-to-190-countries-in-7-years.

Buckley, P. J., \& Casson, M. C. 2009. The internalisation theory of the multinational enterprise: A review of the progress of a research agenda after 30 years. Journal of International Business Studies, 40(9): 1563-1580.

Cardon, M. S., \& Kirk, C. P. 2015. Entrepreneurial passion as mediator of the self-efficacy to persistence relationship. Entrepreneurship Theory and Practice, 39(5): 1027-1050.

Caves, R. E. 1971. International corporations: The industrial economics of foreign investment. Economica, 38(149): 1-27.

Cavusgil, S. T., \& Knight, G. 2015. The born global firm: An entrepreneurial and capabilities perspective on early and rapid internationalization. Journal of International Business Studies, 46(1): 3-16.

Chabowski, B. R., \& Mena, J. A. 2017. A review of global competitiveness research: Past advances and future directions. Journal of International Marketing, 25(4): 1-24.

Chang, S. J., \& Rhee, J. H. 2011. Rapid FDI expansion and firm performance. Journal of International Business Studies, 42(8): 979-994.

Chauvet, M. \& Leleux, B. 2019. Beekeeper: From pivoting startup to disrupting scaleup. Case IMD-7-2027, International Institute for Management Development, Lausanne, Switzerland.
Chetty, S., Johanson, M., \& Martín-Martín, O. 2014. Speed of internationalization: Conceptualization, measurement and validation. Journal of World Business, 49(4): 633-650.

Chliova, M., \& Ringov, D. 2017. Scaling impact: Template development and replication at the base of the pyramid. Academy of Management Perspectives, 31(1): 44-62.

Cohen, R. 2020. The founder of Chewy.com on finding the financing to achieve scale. Harvard Business Review, 98(1): 35-38.

Cohen, W. M., \& Levinthal, D. A. 1990. Absorptive capacity: a new perspective on learning and innovation. Administrative Science Quarterly, 35(1): 128-152.

Contractor, F. J. 2007. Is international business good for companies? The evolutionary or multi-stage theory of internationalization vs. the transaction cost perspective. Management International Review, 47(3): 453-475.

Couper, C., \& Reuber, A. R. 2013. Success in fast growth markets: Strategies for smaller players. Publication 14-018. Global Commerce Centre, Conference Board of Canada. https://www.conferenceboard.ca/e-library/abstract.aspx?did= 5673

Couper, C., Reuber, A. R., \& Prashantham, S. 2020. Lost that lovin' feeling: The erosion of trust between small, highdistance partners. Journal of International Business Studies, 51(3): 326-352.

Coutu, S. 2014. The scale-up manifesto: Why scale-ups will drive the global policy agenda for the next generation. London: Information Economy Council.

Dees, G., Anderson, B. B., \& Wei-Skillern, J. 2004. Scaling social impact: Strategies for spreading social innovations. Stanford Social Innovation Review, 1(4): 24-32.

Demir, R., Wennberg, K., \& McKelvie, A. 2017. The strategic management of high-growth firms: A review and theoretical conceptualization. Long Range Planning, 50(4): 431-456.

Dencker, J. C., Gruber, M., \& Shah, S. K. 2009. Pre-entry knowledge, learning, and the survival of new firms. Organization Science, 20(3): 516-537.

DeSantola, A., \& Gulati, R. 2017. Scaling: Organizing and growth in entrepreneurial ventures. Academy of Management Annals, 11(2): 640-668.

Dierickx, I., \& Cool, K. 1989. Asset stock accumulation and sustainability of competitive advantage. Management Science, 35(12): 1504-1511.

Duruflé, G., Hellmann, T., \& Wilson, K. 2018. From start-up to scale-up: Examining public policies for the financing of highgrowth ventures. In C. Mayer, S. Miscossi, M. Onado, M. Pagano, \& A. Polo (Eds.): Finance and investment: The European case. Oxford: Oxford University Press.

Eisenhardt, K. M., \& Schoonhoven, C. B. 1990. Organizational growth: Linking founding team, strategy, environment, and growth among U.S. semiconductor ventures, 1978-1988. Administrative Science Quarterly, 35(3): 504-529.

Erasmus Centre for Entrepreneurship 2018. Fast growth among established companies; growth in young scale-ups halts. https://ece.nl/fast-growth-among-established-companiesgrowth-in-young-scale-up-halts/. Accessed 20 February 2020.

Fan, T., \& Phan, P. 2007. International new ventures: revisiting the influences behind the 'born-global' firm. Journal of International Business Studies, 38(7): 1113-1131.

Feldman, M. S., \& Pentland, B. T. 2003. Reconceptualizing organizational routines as a source of flexibility and change. Administrative Science Quarterly, 48(1): 94-118. 
Fernhaber, S. A., \& McDougall-Covin, P. P. 2009. Venture capitalists as catalysts to new venture internationalization: the impact of their knowledge and reputation resources. Entrepreneurship Theory and Practice, 33(1): 277-295.

Fischer, E., \& Reuber, R. 2007. The good, the bad, and the unfamiliar: The challenges of reputation formation facing new firms. Entrepreneurship Theory and Practice, 31(1): 53-75.

Fiss, P. 2011. Building better causal theories: A fuzzy set approach to typologies in organization research. Academy of Management Journal, 54(2): 393-420.

Garnsey, E. 1998. A theory of the early growth of the firm. Industrial \& Corporate Change, 7(3): 523-556.

Ghoshal, S., \& Bartlett, C. A. 1988. Creation, adoption, and diffusion of innovations by subsidiaries of multinational corporations. Journal of International Business Studies, 19(3): 365-388.

Gilbert, B. A., McDougall, P. P., \& Audretsch, D. B. 2008. Clusters, knowledge spillovers and new venture performance: An empirical examination. Journal of Business Venturing, 23(4): 405-422.

Gimeno, J., Folta, T. B., Cooper, A. C., \& Woo, C. Y. 1997. Survival of the fittest? Entrepreneurial human capital and the persistence of underperforming firms. Administrative Science Quarterly, 42(4): 750-783.

Goerzen, A., Asmussen, C. G., \& Nielsen, B. B. 2013. Global cities and multinational enterprise location strategy. Journal of International Business Studies, 44(5): 427-450.

Gulati, R., Puranam, P., \& Tushman, M. 2012. Meta-organization design: Re-thinking design in interorganizational and community contexts. Strategic Management Journal, 33(6): $571-586$.

Gupta, A. K., \& Govindarajan, V. 2000. Knowledge flows within multinational corporations. Strategic Management Journal, 21(4): 473-496.

Håkanson, L., \& Kappen, P. 2017. The 'Casino Model' of internationalization: An alternative Uppsala paradigm. Journal of International Business Studies, 48(9): 1103-1113.

Hambrick, D. C., \& Crozier, L. M. 1985. Stumblers and stars in the management of rapid growth. Journal of Business Venturing, 1(1): 31-45.

Hashai, N. 2011. Sequencing the expansion of geographic scope and foreign operations by "born global" firms. Journal of International Business Studies, 42(8): 995-1015.

Hathaway, I. 2018. High-growth firms and cities in the U.S.: An analysis of the Inc. 5000. Metropolitan Policy Program, Brookings Institution. https://www.brookings.edu/research/ high-growth-firms-and-cities-in-the-us-an-analysis-of-the-inc5000/. Accessed 17 December 2020.

Hennart, J. F. 2007. The theoretical rationale for a multinationality-performance relationship. Management International Review, 47(3): 423-452.

Hennart, J. F. 2014. The accidental internationalists: A theory of born globals. Entrepreneurship Theory and Practice, 38(1): 117-135.

Hinds, P., Liu, L., \& Lyon, J. 2011. Putting the global in global work: A intercultural lens on the practice of cross-national collaboration. Academy of Management Annals, 5(1): 135-188.

Huang, J., Henfridsson, O., Liu, M. J., \& Newell, S. 2017. Growing on steroids: Rapidly scaling the user base of digital ventures through digital innovation. MIS Quarterly, 41(1): 301-314.

Isenberg, D., \& Lawton, D. 2014. How to Finance the Scale-Up of Your Company. Harvard Business Review Digital Articles. https://hbr.org/2014/08/how-to-finance-the-scale-up-ofyour-company. Accessed 20 February 2020.

Izosimov, A. V. 2008. Managing hypergrowth. Harvard Business Review, 86(4): 121-127.

Jonsson, A., \& Foss, N. J. 2011. International expansion through flexible replication: Learning from the internationalization experience of IKEA. Journal of International Business Studies, 42(9): 1079-1102.
Kano, L. 2018. Global value chain governance: A relational perspective. Journal of International Business Studies, 49(6): 684-705.

Kano, L., \& Verbeke, A. 2015. The three faces of bounded rationality: Alfred Chandler and the Micro-foundations of management theory. California Management Review, 58(1): 97-122.

Katz, M. L., \& Shapiro, C. 1994. Systems competition and network effects. Journal of Economic Perspectives, 8(2): 93-115.

Knight, G. A., \& Cavusgil, S. T. 2004. Innovation, organizational capabilities, and the born-global firm. Journal of International Business Studies, 35(2): 124-141.

Kretschmer, T., Leiponen, A., Schilling, M., \& Vasudeva, G. 2020. Platform ecosystems as meta-organizations: Implications for platform strategies. Strategic Management Journal.. https://doi.org/10.1002/smj.3250.

Larsen, M. M., Manning, S., \& Pedersen, T. 2013. Uncovering the hidden costs of offshoring: The interplay of complexity, organizational design, and experience. Strategic Management Journal, 34(5): 533-552.

Levitt, T. 1983. The globalization of markets. Harvard Business Review, 61, 92-102.

Lim, D., \& Chandrasekhar, R. 2018. Freshii Inc.: Scaling up culture. Case W18716. London: Ivey Business School.

Lovelock, C. H., \& Yip, G. S. 1996. Developing global strategies for service businesses. California Management Review, 38(2): 64-86.

Markman, G. D., \& Gartner, W. B. 2002. Is extraordinary growth profitable? A study of Inc. 500 high-growth companies. Entrepreneurship Theory and Practice, 27(1): 65-75.

McDougall, P. P., Shane, S., \& Oviatt, B. M. 1994. Explaining the formation of international new ventures: The limit of theories from international business research. Journal of Business Venturing, 9(6): 469-487.

Monaghan, S., \& Tippmann, E. 2018. Becoming a multinational enterprise: Using industry recipes to achieve rapid multinationalization. Journal of International Business Studies, 49(4): 473-495.

Monaghan, S., Tippmann, E., \& Coviello, N. 2020. Born digitals: Thoughts on their internationalization and a research agenda. lournal of International Business Studies, 51(1): 11-22.

Morris, S., Snell, S., \& Björkman, I. 2016. An architectural framework for global talent management. Journal of International Business Studies, 47(6): 723-747.

Nohria, N., \& Ghoshal, S. 1994. Differentiated fit and shared values: Alternatives for managing headquarters-subsidiary relations. Strategic Management Journal, 15(6): 491-502.

Orleans, A., \& Siegel, R. 2019. SurveyMonkey in 2018. Case E-654. Stanford Graduate School of Business.

Osegowitsch, T., \& Sammartino, A. 2008. (Home-)Regionalisation. Journal of International Business Studies, 39(2): 184-196.

Oviatt, B. M., \& McDougall, P. P. 1994. Toward a theory of international new ventures. Journal of International Business Studies, 25(1): 45-64.

Penrose, E. 1959/1995. The theory of the growth of the firm. Oxford: Oxford University Press.

Piaskowska, D., Tippmann, E., \& Monaghan, S. 2021. Scale-up modes: Profiling activity configurations in scaling strategies. Long Range Planning, in press.

Pitelis, C. 2020. Mega tech, unicorns, and the sharing economy: Can Penrose and Hymer help us predict? Strategic Management Review, forthcoming.

Porter, M. E. 1986. Changing patterns of international competition. California Management Review, 28(2): 9-40.

Prahalad, C. K., \& Doz, Y. L. 1987. The multinational mission: Balancing local demands and global vision. New York: Free Press.

Ramaswamy, K., \& Hellpap, R. 2020. OYO: A new global chain of hotels emerges. Case TB0577. Phoenix, AZ: Thunderbird School of Global Management. 
Reiche, B. S., Lee, Y., \& Allen, D. G. 2019. Actors, structure, and processes: A review and conceptualization of global work integrating IB and HRM research. Journal of Management, 45(2): 359-383.

Reuber, A. R. 2018. Research themes about international entrepreneurship: Tales from the JIBS backlist and onward journeys. In A. R. Reuber (Ed.), International Entrepreneurship:The Pursuit of Opportunities Across National Borders. New York: Palgrave Macmillan Springer.

Reuber, A. R., \& Fischer, E. 1997. The role of management's international experience in the internationalization of smaller firms. Journal of International Business Studies, 28(4): 807-825.

Reuber, A. R., \& Fischer, E. 1999. Domestic market size, competences, and the internationalization of small- and medium-sized enterprises. In A. M. Rugman, \& R. W. Wright (Eds.), Research in global strategic management 7 (pp. 85-100). Stanford, CT: JAI

Roberts, P. W., \& Dowling, G. R. 2002. Corporate reputation and sustained superior financial performance. Strategic Management Journal, 23(12): 1077-1093.

Rosenthal, S., Burgelman, R., \& Siegel, R. 2014. Case E-524 SurveyMonkey in 2014. Case E-524. Stanford Graduate School of Business.

Rugman, A. M., \& Verbeke, A. 2001. Subsidiary-specific advantages in multinational enterprises. Strategic Management Journal, 22(3): 237-250.

Rugman, A. M., \& Verbeke, A. 2003. Extending the theory of the multinational enterprise: Internalization and strategic management perspectives. Journal of International Business Studies, 34(2): 125-137.

Rugman, A. M., \& Verbeke, A. 2004. A perspective on regional and global strategies of multinational enterprises. Journal of International Business Studies, 35(1): 3-18.

Rugman, A. M., \& Verbeke, A. 2008. A new perspective on the regional and global strategies of multinational services firms. Management International Review, 48(4): 397-411.

Santangelo, G., \& Meyer, K. 2017. Internationalization as an evolutionary process. Journal of International Business Studies, 48(9): 1114-1130.

Scale Up Europe (2016. A Manifesto for Change and Empowerment in the Digital Age. Lisbon Council, Nesta and Open Evidence.

Scale Up Institute. 2019. Annual scale up review. London: ScaleUp Institute. https://www.scaleupinstitute.org.uk/ scaleup-review/. Accessed 1 March 2020.

Schifrin, D., \& Davis, A. 2016. Vaccine vial monitors: "The little big thing" taking social innovation to scale. Case SI-145. Stanford, CA: Stanford Graduate School of Business.

Schilling, M. A. 2002. Technology success and failure in winnertake-all markets: The impact of learning orientation, timing, and network externalities. Academy of Management Journal, 45(2): 387-398.

Shamsie, J. 2003. The context of dominance: an industry-driven framework for exploiting reputation. Strategic Management Journal, 24(3): 199-215.

Stallkamp, M., \& Schotter, A. P. 2021. Platforms without borders? The international strategies of digital platform firms. Global Strategy Journal, 11(1): 58-80.

Sullivan, T. 2016. Blitzscaling: The chaotic, sometimes grueling path to high-growth, high-impact entrepreneurship. Harvard Business Review, 94(4): 44-50.

Szulanski, G., \& Jensen, R. J. 2006. Presumptive adaptation and the effectiveness of knowledge transfer. Strategic Management Journal, 27(10): 937-957.

Szulanski, G., \& Jensen, R. J. 2008. Growing through copying: The negative consequences of innovation on franchise network growth. Research Policy, 37(10): 1732-1741.

Tallman, S., Luo, Y., \& Buckley, P. J. 2018. Business models in global competition. Global Strategy Journal, 8(4): 517-535.
Teece, D. J. 2014. A dynamic capabilities-based entrepreneurial theory of the multinational enterprise. Journal of International Business Studies, 45(1): 8-37.

Tippmann, E., \& Monaghan, S. 2018. Qualtrics: Rapid international expansion. Case W18076. London: Ivey Business School.

Vahlne, J.-E., \& Johanson, J. 2017. From internationalization to evolution: The Uppsala model at 40 years. Journal of International Business Studies, 48(9): 1087-1102.

Van Alstyne, M. W., Parker, G. G., \& Choudary, S. P. 2016. Pipelines, platforms, and the new rules of strategy. Harvard Business Review, 94(4): 54-62.

Venaik, S., Midgley, D. F., \& Devinney, T. M. 2005. Dual paths to performance: The impact of global pressures on MNC subsidiary conduct and performance. Journal of International Business Studies, 36(6): 655-675.

Verbeke, A. 2013. International Business Strategy. Cambridge: Cambridge University Press.

Verbeke, A., Coeurderoy, R., \& Matt, T. 2018. The future of international business research on corporate globalization that never was.... Journal of International Business Studies, 49(9): 1101-1112.

Verbeke, A., \& Forootan, M. Z. 2012. How good are multinationality-performance (M-P) empirical studies? Global Strategy Journal, 2(4): 332-344.

Verbeke, A., \& Greidanus, N. 2009. The end of opportunism vs trust debate: Bounded reliability as a new envelope concept in research on MNE governance. Journal of International Business Studies, 40(9): 1471-1495.

Verbeke, A., \& Hutzschenreuter, T. 2021. The dark side of digital globalization. Academy of Management Perspectives, forthcoming.

Vermeulen, F., \& Barkema, H. 2002. Pace, rhythm, and scope: Process dependence in building a profitable multinational corporation. Strategic Management Journal, 23(7): 637-653.

Wining, L., \& Eaves, D. 2020. The quest for achieving financial inclusion: M-Pesa versus UPI. Case K1304. Cambridge, MA: Harvard Kennedy School.

Winter, S. G., \& Szulanski, G. 2001. Replication as strategy. Organization Science, 12(6): 730-743.

Winter, S. G., Szulanski, G., Ringov, D., \& Jensen, R. J. 2012. Reproducing knowledge: Inaccurate replication and failure in franchise organizations. Organization Science, 23(3): 672-685.

World Economic Forum 2016. Mastering hypergrowth. http:// reports.weforum.org/mastering-hypergrowth/infographics/ ?doing_wp_cron=1535032589.1179521083831787109375. Accessed $2 \overline{3}$ August 2018.

Yang, J. Y., Lu, J., \& Jiang, R. 2017. Too slow or too fast? Speed of FDI expansions, industry globalization, and firm performance. Long Range Planning, 50(1): 74-92.

Zahra, S. A., Ireland, R. D., \& Hitt, M. A. 2000. International expansion by new venture firms: International diversity, mode of market entry, technological learning, and performance. Academy of Management Journal, 43(5): 925-950.

Zhou, L., Wu, W.-P., \& Luo, X. 2007. Internationalization and the performance of born-global SMEs: The mediating role of social networks. Journal of International Business Studies, 38(4): 673-690.

Zook, C., \& Allen, J. 2012. Repeatability: Building enduring businesses for a world of constant change. Boston: Harvard Business School.

Zott, C., Amit, R., \& Massa, L. 2011. The business model: Recent developments and future research. Journal of Management, 37(4): 1019-1042.

\section{ABOUT THE AUTHORS}

A. Rebecca Reuber (PhD, Queen's University) is Professor of Strategic Management at the Rotman School of Management, University of Toronto, 
Canada. Her research examines firm-level internationalization with an entrepreneurship lens, mostly in the context of new firms and small firms. She is a Fellow of the Academy of International Business, a V.P. Administration on the AIB Executive Board, and an Area Editor of Journal of International Business Studies.

Esther Tippmann (PhD, TU Dublin) is Professor of Strategy, Leadership and Change at National University of Ireland Galway. Her research focuses on global strategy, including strategies of scaling digital firms. It has been published in the top journals of these areas, including the Journal of International Business Studies, Journal of World
Business, and Global Strategy Journal. She serves as a Senior Editor for the Journal of World Business

Sinéad Monaghan (PhD, University of Limerick) is Associate Professor of International Business and Global Strategy at Trinity College Dublin. Her research focuses on rapid multinationalization, global scaling and location choice. Her work has been published in Journal of International Business Studies, British Journal of Management, and Journal of Business Research. She is on the Editorial Board of Journal of International Business, Journal of World Business, and Transnational Corporations.

Publisher's Note Springer Nature remains neutral with regard to jurisdictional claims in published maps and institutional affiliations.

Accepted by Alain Verbeke, Editor-in-Chief, 13 February 2021. This article has been with the authors for two revisions. 